\title{
Bovine Manure as a Rich Source for Isolation of Halo- Tolerant Bacterial Strains Capable of PAHs Biodegradation in Slurry Bioreactor
}

\author{
Neamat Jaafarzadeh ${ }^{1,2}$, Sahand Jorfi ${ }^{1,2}$, Azadeh Mirzaiy ${ }^{1,2}$, Zeinab Ghaedrahmat ${ }^{3,4 *}$ (D) \\ 1 Department of Environmental Health Engineering, School of Health, Ahvaz Jundishapur University of Medical Sciences, \\ Ahvaz, Iran \\ 2 Environmental Technologies Research Center, Ahvaz Jundishapur University of Medical Sciences, Ahvaz, Iran \\ 3 Department of Environmental Health Engineering, Student Research Committee, Ahvaz Jundishapur University of \\ Medical Sciences, Ahvaz, Iran \\ 4 Department of Environmental Health Engineering, Shoushtar Faculty of Medical Sciences, Shoushtar, Iran \\ * Correspondence: z_rahmati4007@yahoo.com;
}

Scopus Author ID 57190034269

Received: 27.02.2021; Revised: 25.03.2021; Accepted: 27.03.2021; Published: 7.04.2021

\begin{abstract}
This study aimed to isolate a bacterial consortium that capable of decomposing PAHs. Three halo-tolerant bacterial strains of Microbacterium paraoxydans B3F (S1), Stenotrophomonas N3 (S2), and Citrobacter NB2 (S3) were isolated from bovine manure. The isolate Microbacterium paraoxydans $\mathrm{B} 3 \mathrm{~F}$ showed the least resistance to salinity and growth not observed at 2 and $2.5 \%$ of $\mathrm{NaCl}$, while isolate Citrobacter NB2 indicated growth in all salinity levels. The PHE biodegradation was more efficient in bacterial consortium compared to pure culture. At the end of the 35th day, the removal efficiency of PHE with an initial concentration of $100 \mathrm{mg} / \mathrm{kg}$ for seed volumes of 2, 10, and $20 \mathrm{~mL}$ was $33 \%, 50 \%$, $52 \%$, respectively. The TPHs biodegradation efficiencies at different soil/water ratios of $25 \%, 50 \%$ and $100 \%$ were $12 \%, 28.7 \%$ and $60.8 \%$, respectively. Three halo-tolerant bacteria were isolated from Bovine manure were efficiently used for bioremediation of phenanthrene.
\end{abstract}

Keywords: : phenanthrene; bioremediation; salinity; slurry bioreactor

(C) 2021 by the authors. This article is an open-access article distributed under the terms and conditions of the Creative Commons Attribution (CC BY) license (https://creativecommons.org/licenses/by/4.0/).

\section{Introduction}

American Environmental Protection Agency (EPA) was identified 16 cyclic aromatic hydrocarbons as pollutants, eight of which are carcinogenic and abundant in the environment. Cyclic aromatic hydrocarbons (PAHs), due to their high dissociation coefficient, can be adsorbed on the surface of particles and deposited in the soil environment. PAHs contain two or more benzene rings. These rings are connected in a linear, angular, and clustered shape [1, 2]. These hydrocarbons have high resistance in the environment due to their high hydrophobic properties. Generally, with increasing the number of benzene rings in cyclic aromatic hydrocarbons, their solubility in water decreases, and they have higher durability in the environment. PAHs are produced by both natural and artificial factors. Natural sources of PAHs include forest fires and oil spills. Synthetic sources of PAHs include the incomplete combustion of coal fossil fuels, incomplete combustion of crude oil and wood [1, 3-7].

One of the PAHs compounds is phenanthrene, which has low biodegradability and stability in the environment. Thus, it must be decomposed before being released into the environment [2]. Petroleum hydrocarbons are highly durable in the soil, and their presence in 
the soil poses a risk of transfer to water sources and causes toxicity and hazard to humans and other living organisms. So, they must be somehow removed from the environment [8]. There are several physical and chemical methods to deal with oil pollution in the soil, many of which are less commonly used due to their high cost and harmful side effects. Bacteria found in the environment have been used to remove these compounds from soil. Today, several microorganisms species are known in nature or are being isolated [3-5, 9].

Compared to other methods, the bioremediation method's advantages can be less cost of this method, fewer negative environmental effects, simplicity of its technology, low initial running costs, the possibility of the complete destruction of pollutants, and no need for specialized equipment [10-13]. Since phenanthrene is one of the PAHs that are dangerous to the environment and toxic to humans. The PAHs enter the soil through oil sludge, the wastewater of refineries, and enter the groundwater through the soil, causing groundwater and drinking water pollution. Therefore, it is necessary to effectively remove them from oilcontaminated soils [14].

Bioremediation technology's main purpose is to remove contaminants from the natural environment or convert these contaminants into less toxic compounds using the native microbial population in the contaminated environment [15-19]. The bioremediation process can be improved by biostimulation (addition of bulking agents such as wood chips or nutrients such as nitrogen, phosphorus, and potassium) and bioavailability (inoculation of microorganisms capable of converting pollutants into less toxic or non-toxic compounds) [2022]. Bioregeneration or the addition of oil-degrading microorganisms is a complementary method for bioremediation of oil-contaminated sites; indigenous microbial populations cannot decompose a wide range of substrates in the complex crude oil composition, or indigenous microbial populations may be affected by oil spill stress. Also, the population of oil decomposers may be small. The success of bioremediation depends on the use of environmentally friendly microbial species [23-25].

Some natural or synthetic organic compounds such as aromatic hydrocarbons, pesticides, chlorinated hydrocarbons, etc., are resistant to microorganisms' action. Conversion of these compounds requires bacterial enrichment and strain identification through a biochemical or molecular detection assay such as polymerase chain reaction (PCR). Therefore, based on the light of the foregoing description and the contamination of the soils of Khuzestan province with petroleum compounds and the salinity characteristic of these soils, the present study was designed to isolate a bacterial consortium capable of decomposing PAHs. Bovine manure is also an inexpensive and easy source of rich microflora and therefore has been selected as the source for isolation of microorganisms in this study. So, in this work, three halotolerant bacteria Microbacterium paraoxydans B3F (S1), Stenotrophomonas N3 (S2), and Citrobacter NB2 (S3), were isolated from bovine manure and then applied for bioremediation of PHE contaminated soil.

\section{Materials and Methods}

\subsection{Chemicals.}

The chemicals compound were provided from Sigma Aldrich, UK. Chemical solvents including HPLC-grade PHE, $n$-hexane, methanol, trichloromethane, sulphuric acid (95-97 \%), sodium hydroxide, and culture media constituents Reagents and enzymes for polymerase chain 
reaction (PCR) were provided from Sigma Aldrich, UK. All chemicals were of analytical grade ( $\geq 99 \%$ purity).

\subsection{Isolation of PHE-degrading bacteria.}

For bacterial strain isolation, $100 \mathrm{~g}$ of bovine manure was added to a $250-\mathrm{mL}$ container with $100 \mathrm{~mL}$ phosphate mineral salt (PMS) medium. The solution was stirred (10 min) and then settled. Afterward, $10 \mathrm{~mL}$ of the settled solution was moved to a $250-\mathrm{mL}$ container with $100 \mathrm{~mL}$ of PMS. The PMS medium components including: $\left(\mathrm{g} \mathrm{L}^{-1}\right): \mathrm{K}_{2} \mathrm{HPO}_{4}: 6.3, \mathrm{CaCl}_{2} \cdot \mathrm{H}_{2} \mathrm{O}$ : $0.1, \mathrm{MgSO}_{4} \cdot 7 \mathrm{H}_{2} \mathrm{O}: 0.1, \mathrm{MnSO}_{4} \cdot \mathrm{H}_{2} \mathrm{O}: 0.1, \mathrm{FeSO}_{4} \cdot 7 \mathrm{H}_{2} \mathrm{O}: 0.1$, and $1 \mathrm{~mL} \mathrm{~L}^{-1}$ of trace elements solution. The component of solution containing trace elements including $\left(\mathrm{g} \mathrm{L}^{-1}\right) \mathrm{H}_{3} \mathrm{BO}_{3}: 0.03$, $\mathrm{CoCl}_{2} \cdot 6 \mathrm{H}_{2} \mathrm{O}: 0.02, \mathrm{ZnSO}_{4} \cdot 7 \mathrm{H}_{2} \mathrm{O}: 0.01, \mathrm{CuSO}_{4} \cdot 2 \mathrm{H}_{2} \mathrm{O}: 0.001, \mathrm{Na}_{2} \mathrm{MoO}_{4}: 0.006$. The sole source of carbon and energy for enriching the PHE-degrading consortium was PHE that added a concentration of $1 \%(\mathrm{~V} / \mathrm{V})$ into the medium [26]. PHE was first dissolved in n-hexane and afterward added to the culture medium. The salinity of the medium was adjusted to $1.5 \%$ using $\mathrm{NaCl}$.

The flasks were incubated at $35^{\circ} \mathrm{C}$ on stirred at $180 \mathrm{rpm}$ for 7 days. Measurement of absorbance at $600 \mathrm{~nm}$ was used to monitor growth. After four weeks, $1 \mathrm{~mL}$ of supernatant culture was diluted $10^{-4}$ times and then extended onto TPHs-coated nutrient agar plates PHEcoated PMS agar plates and incubated for $72 \mathrm{~h}$ at $37^{\circ} \mathrm{C}$. The salinity of the water was changed to $1.5 \%$. Different morphological colonies were determined and spread on nutrient agar plates with a salinity of $4 \%$ to obtain a pure culture.

\subsection{Soil preparation.}

Soil samples were taken near Iran's oil fields are located in the southwest. The soil sample was extracted from 0 to $30 \mathrm{~cm}$ below the ground surface. The samples were passed through a sieve with mesh 2 , dried, autoclaved and stored at $4^{\circ} \mathrm{C}$ before use.

Samples were synthetically contaminated with PHE at pollution levels of 50, 100, and $200 \mathrm{mg} \mathrm{kg}^{-1}$ (dry weight). Pure PHE was dissolved in $\mathrm{n}$-hexane before being added to the samples, mixed, and kept under the hood for $24 \mathrm{~h}$ to PHE was evaporate completely. To evaluate chemical properties of soil, X-ray fluorescence (XRF) analysis was applied. The properties of soil samples were demonstrated in Table 1 . The soil analysis was characterized as a sandy-clay type according to texture assessment analysis with a specific surface area of $10.28 \mathrm{~m}^{2} \mathrm{~g}^{-1}$.

\subsection{Biodegradation evaluation.}

The analysis was conducted in 500-mL containers, and $30 \mathrm{~g}$ (dry weight) soil was moved to containers. The effect of each parameters, including various volumes of inoculums with $\mathrm{OD}_{600 \mathrm{~nm}}=1(5,10,15$ and $20 \mathrm{~mL})$, water content $(50 \%, 100 \%$ and slurry), salinity levels $(0.5,1,1.5$ and $2 \%)$, and various initial PHE concentrations $\left(50,100\right.$ and $\left.200 \mathrm{mg} \mathrm{kg}^{-1}\right)$ were experimenting with one factor at a time design [26, 27].

The containers were shaken at $180 \mathrm{rpm}$ and $37^{\circ} \mathrm{C}$. The residual PHE concentrations were determined during 7 days, and microbial growth was performed weekly for 35 days. The PHE level in the soil sample was evaluated with an ultrasound device base on EPA method 3550B. For extraction of PHE, 3-g air-dried soil samples were subjected to 30 min of shaking at $180 \mathrm{rpm}$, followed by $10 \mathrm{~min}$ of sonication with a $30-\mathrm{mL}$ solvent mixture of acetonitrile and 
methanol $(2: 1, \mathrm{v} / \mathrm{v})$. The residual was dissolved in $4 \mathrm{~mL} n$-hexane for quantitative analysis. PHE concentration was specified by gas chromatography (GC) system (Chrompack CP 9001). The removal was analyzed through quantifying initial and final Phenanthrene concentration base on Eq. (1):

$$
\operatorname{Re} \operatorname{moval}(\%)=\left(\frac{C_{0}-C_{t}}{C_{0}}\right) \times 100
$$

where, $C_{o}$ is the initial concentration of phenanthrene $(\mathrm{mg} / \mathrm{L})$, and $C_{t}$ is the concentration of phenanthrene $\left(\mathrm{mg} \mathrm{L}^{-1}\right)$. PHE recovery rate was about $90 \%$ immediately after spiking. The TPH concentration of samples was specified using an (HP-5) capillary column and a gas chromatography fitted with a flame ionization detector (GC-FID) (Model: Chrompack CP 9001) (30 m length, $0.32 \mathrm{~mm}$ inner diameter, and $0.2 \mathrm{~mm}$ film thickness).

In conclusion, in five replicates in ten series, $1 \mathrm{~mL}$ of microorganism suspension diluted tenfold to $10-10$ in the ringer solution $(8.5 \mathrm{~g} \mathrm{NaCl} \mathrm{L}-1 \mathrm{DW})$ was added to $9 \mathrm{~mL}$ sterile nutrient broth. Ultimately, a collection of bioremediation tests was performed in optimal conditions on an unwashed soil sample Gas chromatography-mass spectrometry (GC-MS) analysis was used to identify the various HCs. (Model: Agilent 7890, USA). At this stage, the growth rate of the strains at various $\mathrm{NaCl}$ concentrations of $0.5 \%, 1 \%, 1.5 \%, 2 \%$, and $2.5 \%$ were studied, so all strains were cultured on a medium containing various concentration of $\mathrm{NaCl}$ and incubated at $37^{\circ} \mathrm{C}$ for 48 to $72 \mathrm{~h}$.

\subsection{Statistics analysis.}

The Excel and SPSS v.23 software were applied for the analysis of the data set. The normality of quantitative data was checked by the Kolmogorov-Smirnov test. The analysis of variance (ANOVA) was used for the statistical evaluation of differences between the results.

\section{Results and Discussion}

\subsection{Bacterial resistance to salinity.}

In the present work, salt concentrations $0.5,1.0,1.5,2.0$ and $2.5 \%(\mathrm{w} / \mathrm{v} \mathrm{NaCl})$ were applied in order to evaluate $\mathrm{NaCl}$ tolerance of strains. The result was indicated that all strains showed good growth in salt concentrations of 0.5 and $1 \%$.

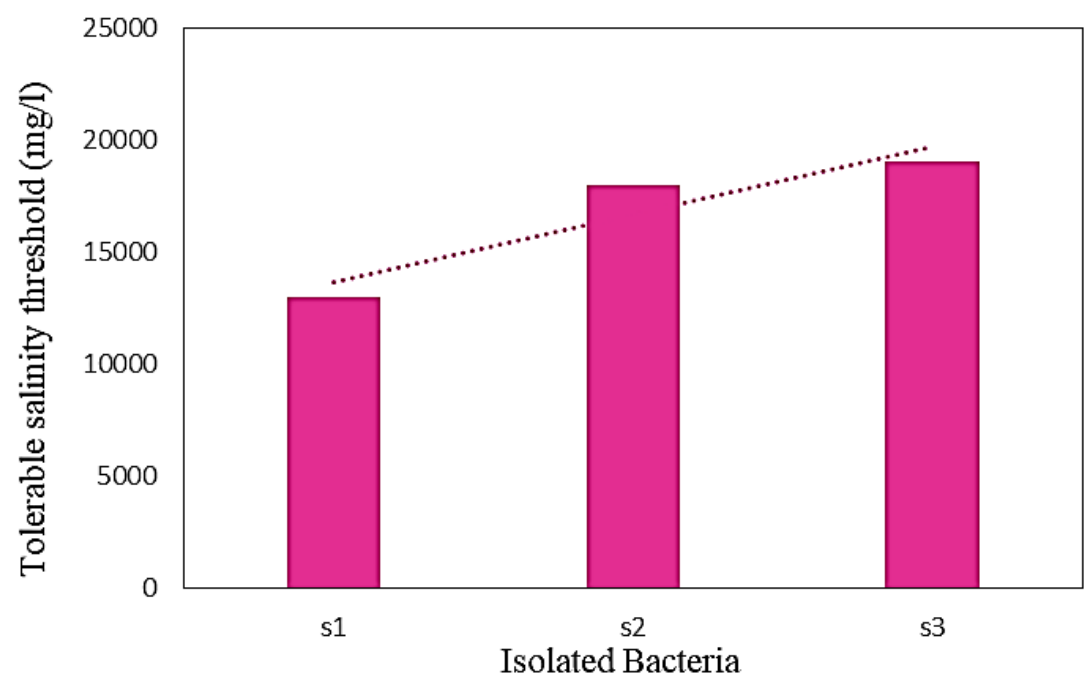

Figure 1. Salt tolerance of isolated bacteria against salinity. 
At a salt concentration of $1.5 \%$, Microbacterium paraoxydans $\mathrm{B} 3 \mathrm{~F}$ and Stenotrophomonas N3 showed good growth, and at a salt concentration of $2 \%$, only Citrobacter $N B 2$ strain was showed good growth, although, at the concentrations of $2.5 \%$, the growth was less (Figure 1). According to Figure 1, the Microbacterium paraoxydans B3F isolate was more sensitive to the existence of salt in the medium, with no growth at 2 and $2.5 \%$ salt, while Citrobacter NB2 isolate indicated growth in all salinity value. Therefore, we can assume that enzyme secretion was decreased in high salt concentration, enzymes could not be active fully or decrease in growth of microorganism [28, 29]. Figure 2 shows the colony of the isolated bacterium on nutrient agar.

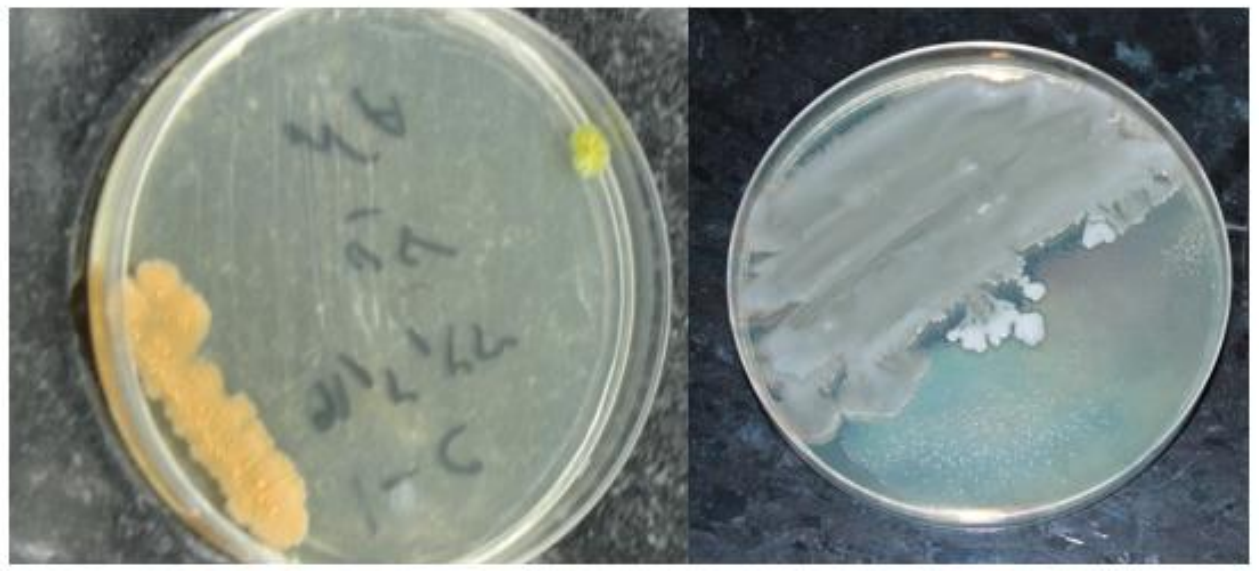

Figure 2. The colony of the isolated bacterium on nutrient agar.

\subsection{PHE biodegradation by pure strains.}

A biodegradation assay was performed to determine the indigenous bacterial isolates' PHE degradation capabilities from bovine manure. PHE were added separately at $1 \%(\mathrm{v} / \mathrm{v})$ to PMS medium, and the incubation was carried out for a period of 35 days for PHE degradation. The pure culture of Stenotrophomonas N3 has indicated the highest biodegradation rate of 26\%, corresponding to the highest growth rate (log MPN: 6.113943) when the incubation time is over (35day).

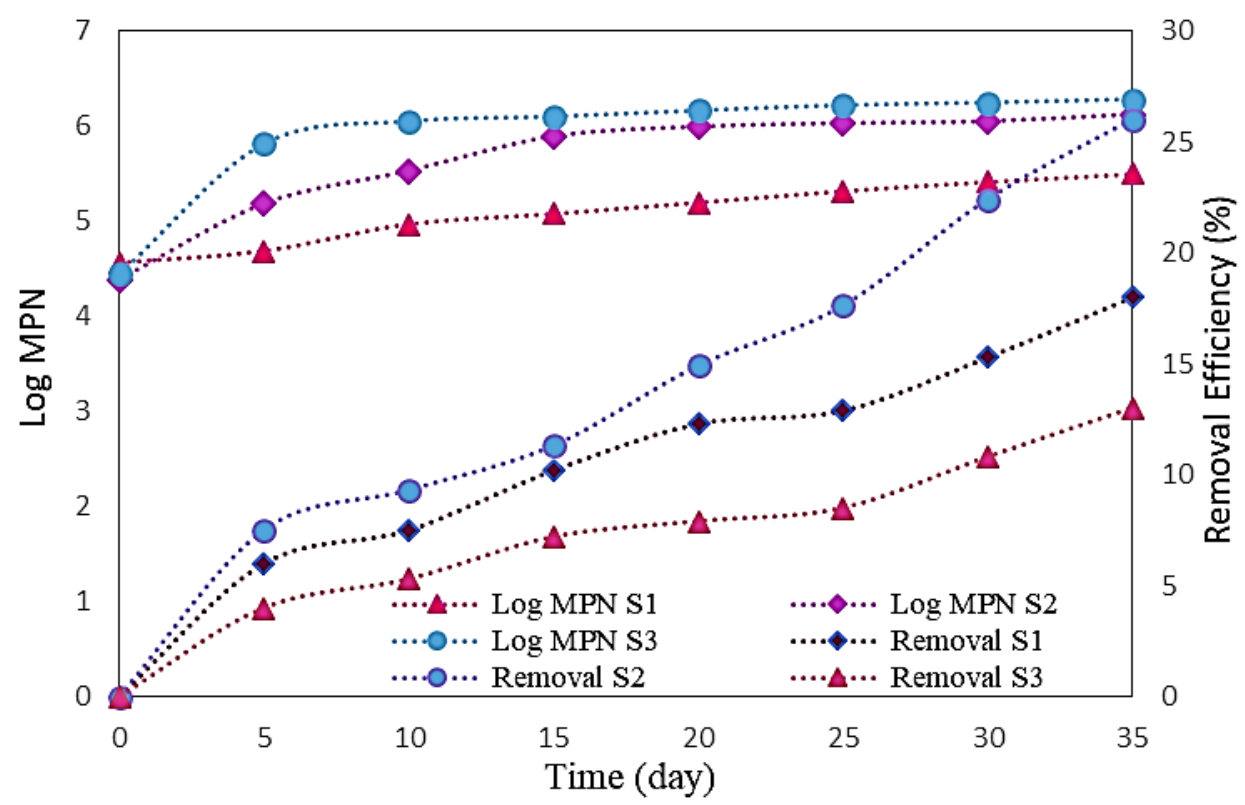

Figure 3. Removal efficiency of PHE by isolated (Moisture: 100\%, PHE: 100mg/kg, $\mathrm{OD}_{600}=1: 5 \mathrm{~mL}$, Reaction time: 35day). 
The pure strains of Microbacterium paraoxydans B3F and Citrobacter NB2 were removed PHE by a degradation rate of $18 \%$ and $13 \%$, respectively (Figure 3 ). However, the PAHs degrading activities of the bacterial consortium would be more effective than those pure cultures. The mixed culture was able to degrade PHE by a degradation rate of $34 \%$ (Figure 4 ). Several studies were reported that consortium biodegradation would be more effective than those pure cultures, which may be due to a wider enzymatic susceptibility and counteraction of toxic intermediates by co-metabolic processes [30, 31].

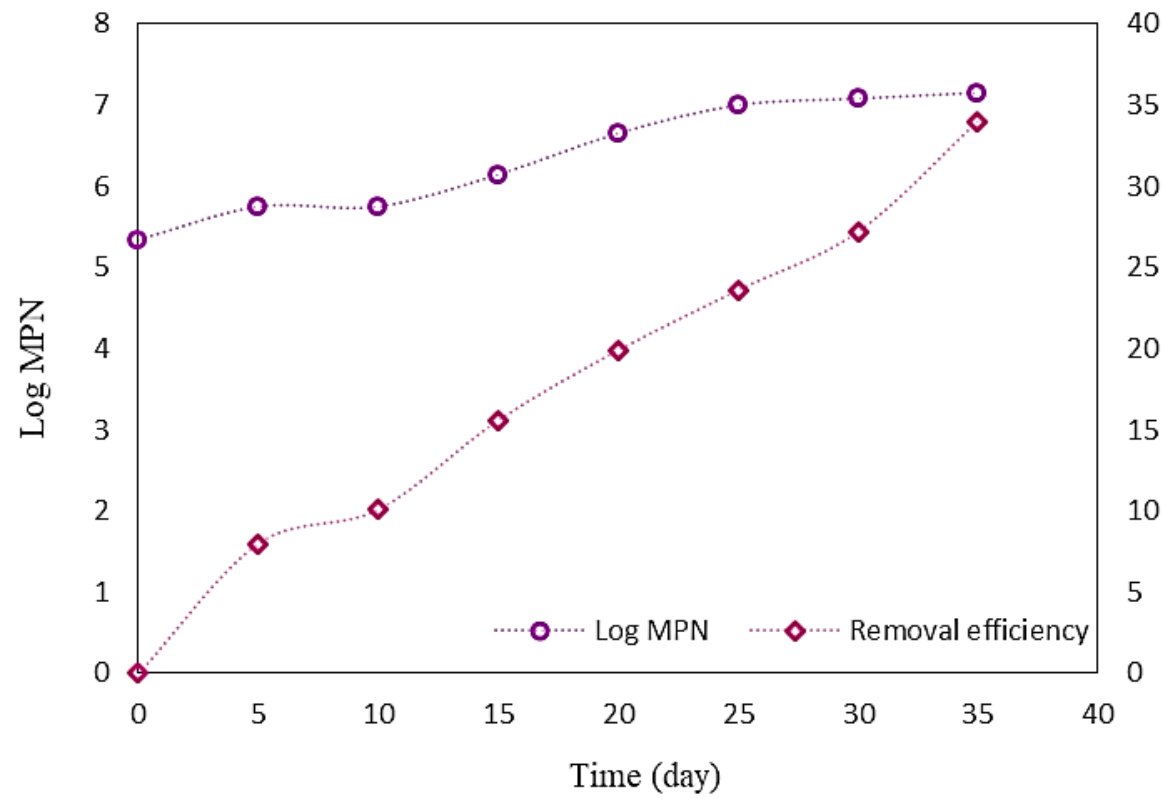

Figure 4. Removal efficiency of PHE by consortium (Moisture: 100\%, PHE: $100 \mathrm{mg} / \mathrm{kg}$, OD600=1:5mL, Reaction time: 35 day).

\subsection{Slurry bioreactor.}

\subsubsection{Effect of initial seed size.}

The results showed that the biodegradation of PHE was affected by the initial volume of bacterial seed in the medium. The slow startup may be due to initial bacterial density. The PHE biodegradation vs. the time indicated an increasing effect together with seed volume up to $15 \mathrm{~mL}$ (Figure 5). At the end of the $35^{\text {th }}$ day, the removal efficiency of PHE with an initial concentration of $100 \mathrm{mg} / \mathrm{kg}$ for the seed volumes of 2, 10, and $20 \mathrm{~mL}$ was $33 \%, 50 \%, 52 \%$, respectively. Analysis of variance was indicated that seed size significantly affected the PHE removal $(P$-value $\leq 0.05)$ (Table 1$)$.

Table 1. Result of ANOVA for the effect of seed size and moisture content on bioremediation.

\begin{tabular}{c|c|c|c|c|c}
$\begin{array}{c}\text { Source of } \\
\text { variation }\end{array}$ & Sum of Squares & $\begin{array}{c}\text { Degree of } \\
\text { freedom }\end{array}$ & Mean Square & F & -value \\
\hline Seed size & 1462.870 & 2 & 731.435 & 3.960 & 0.035 \\
\hline Moisture content & 203639.583 & 2 & 101819.792 & 4.217 & 0.027
\end{tabular}

The removal efficiency was increased accompanying the concentration of seed size. Therefore, the removal efficiency of PHE was related to the number of active microorganisms in the culture $[32,33]$. These results are in line with the results of previous research $[34,35]$. 
Bioaugmentation is a favorable method that plays a key role in the bioremediation of hydrocarbon contaminated soil, mainly in slurry phase bioreactors. Since there was no significant difference between removal efficiency at seed volume of 10 and $20 \mathrm{~mL}$, the value of $10 \mathrm{~mL}$ was selected for further analysis.

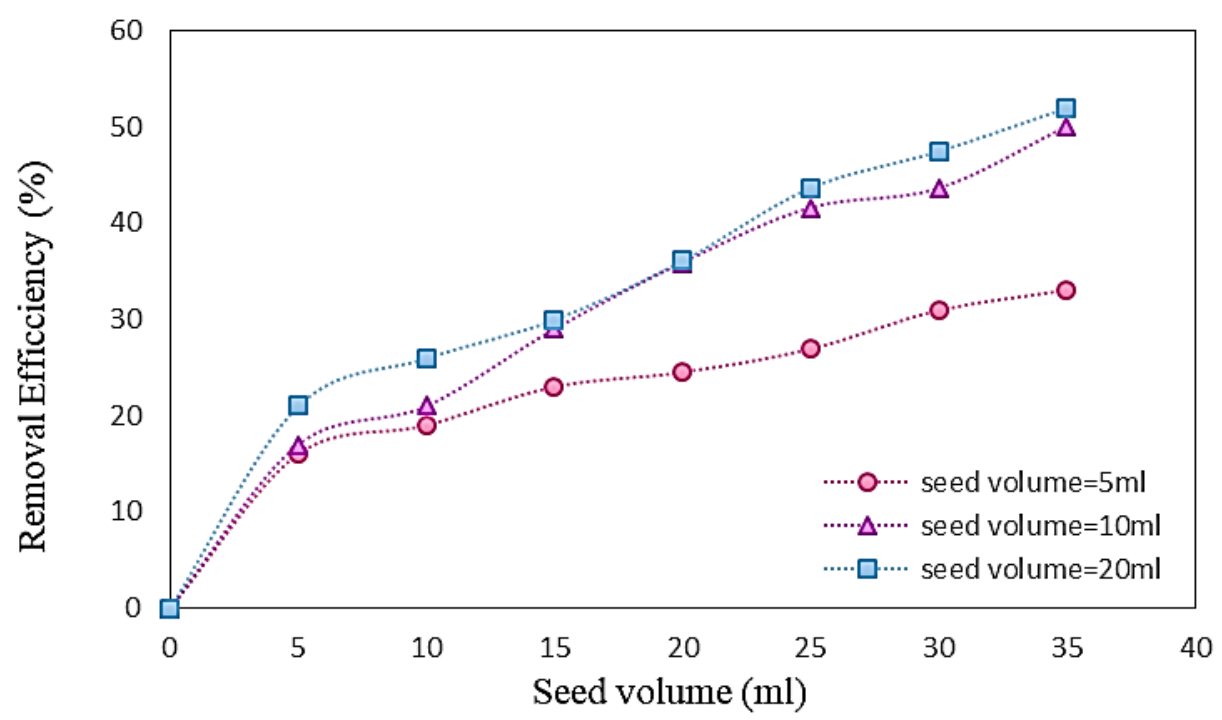

Figure 5. Effect of initial seed size on removal efficiency of PHE (Moisture: 100\%, PHE: 100mg/kg, $\mathrm{OD}_{600}=1: 2.2 \times 5 \mathrm{~mL}$, Reaction time: 35 day).

\subsubsection{Effect of moisture content.}

Water is necessary for the soil to provide microorganisms' physiological requirements and transport the nutrients and metabolic by-products into or out of the cell. Hence, soil biological activity depends on the presence of an adequate water level in the soil. Moreover, soil bacteria generally live in the soil water films $[32,36]$. In this regard, in this study, the effect of soil moisture content was investigated on PHE biodegradation. The result was indicated that moisture content was significantly affected PHE biodegradation $(P$-value $=0.027)($ Table 1$)$.

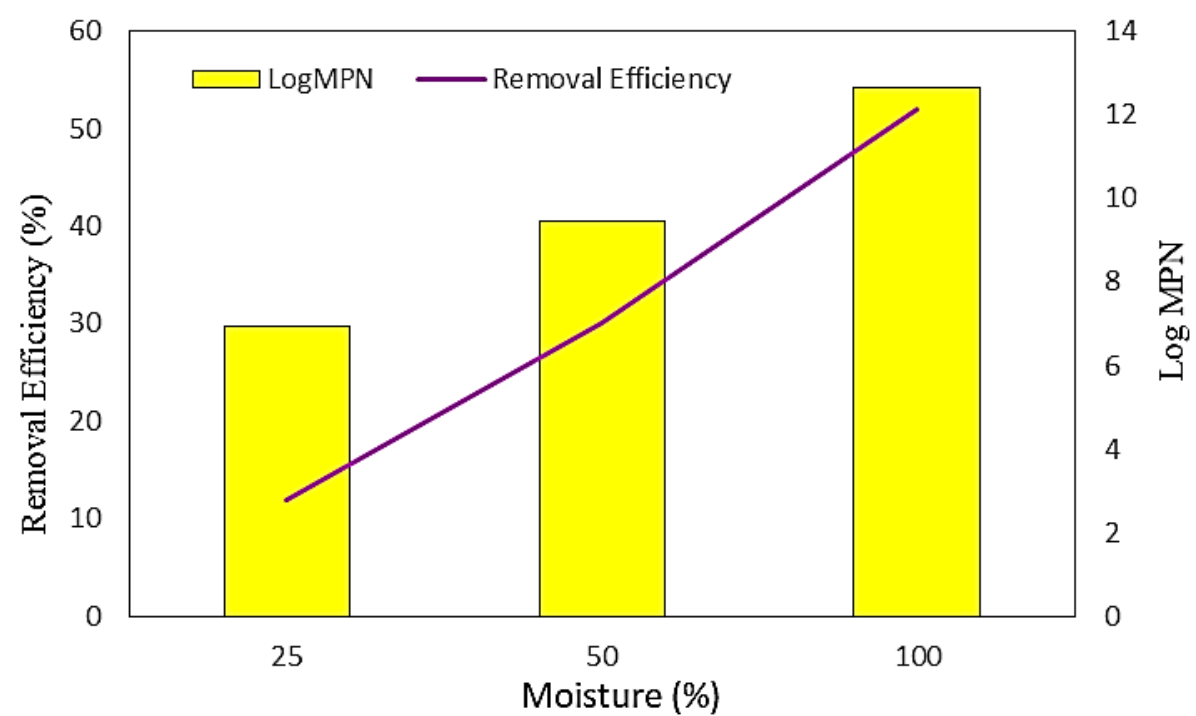

Figure 6. Effect of initial moisture content on removal efficiency of PHE (Seed size: $15 \mathrm{ml}$, PHE: 100mg/kg, $\mathrm{OD}_{600}=1: 2.2 \times 5 \mathrm{~mL}$, Reaction time: 35 days).

The TPHs biodegradation efficiencies at various soil/water ratios of $25 \%, 50 \%$ and $100 \%$ (slurry) were 12\%, $28.7 \%$ and 60.8\%, respectively (Figure 6). Biodegradation of PHE 
increased in the slurry phase, which simplified the bacterial consortium metabolism's metabolism by enhancing the bioavailability and solubilizing the PHE in soil. A previous study indicated that soil's higher moisture contents increased PHE biodegradation and slurry conditions increased the bioremediation of contaminated soil [29, 37-40].

\section{Conclusions}

In the present study, three halo-tolerant bacteria were isolated from Bovine manure and applied for bioremediation of phenanthrene from contaminated soil. The isolate of Microbacterium paraoxydans $B 3 F$ was more sensitive to the existence of salt in the medium, with no growth at 2 and $2.5 \%$ salt, while isolate of Citrobacter NB2 indicated growth in all salinity value. The PAHs degrading activities of the bacterial consortium would be more effective than those pure cultures. The removal efficiency was raised accompanying the concentration of seed size. The TPHs biodegradation efficiencies at different soil/water ratios (slurry) were increased. Three halo-tolerant bacteria were isolated from Bovine manure were efficiently used for bioremediation of phenanthrene from contaminated soil.

\section{Funding}

This research project has been financially supported by the Research Department at Ahvaz Jundishapur University of Medical Sciences (No. 97s36).

\section{Acknowledgments}

This research project has been financially supported by the Research Department at Ahvaz Jundishapur University of Medical Sciences (No. 97s36).

\section{Conflicts of Interest}

The authors declare no conflict of interest.

\section{Reference}

1. Wolf, D.; Cryder, Z.; Khoury, R.; Carlan, C.; Gan, J., Bioremediation of PAH-contaminated shooting range soil using integrated approaches. Science of The Total Environment 2020, 726, 138440, https://doi.org/10.1016/j.scitotenv.2020.138440.

2. Fazilah, A.; Ismail, N.; Darah, I. In Biodegradation of PAH-polluted soil by indigenous bacteria, IOP Conference Series: Earth and Environmental Science, 2020; IOP Publishing: 2020; 012002, https://doi.org/10.1088/1755-1315/494/1/012002.

3. Chang, B.; Shiung, L.; Yuan, S., Anaerobic biodegradation of polycyclic aromatic hydrocarbon in soil. Chemosphere 2002, 48, (7), 717-724, https://doi.org/10.1016/S0045-6535(02)00151-0.

4. Milić, J.; Beškoski, V.; Ilić, M.; Ali, S. A.; Gojgić Cvijović, G.; Vrvić, M., Bioremediation of soil heavily contaminated with crude oil and its products: composition of the microbial consortium. Journal of the Serbian Chemical Society 2009, 74, 455-460, http://dx.doi.org/10.2298/JSC0904455M.

5. Hernández-Rivera, M.; Ojeda-Morales, M.; Martínez-Vázquez, J.; Villegas-Cornelio, V.; Córdova-Bautista, Y., Optimal parameters fort In Vitro development of the hydrocarbonoclastic microorganism Proteus sp. $J$ Soil Sci Plant Nutr 2011, 11, 29-43, http://dx.doi.org/10.4067/S0718-95162011000100003.

6. Forján, R.; Lores, I.; Sierra, C.; Baragaño, D.; Gallego, J. L. R.; Peláez, A. I., Bioaugmentation treatment of a PAH-polluted soil in a slurry bioreactor. Applied Sciences 2020, 10, 2837, https://doi.org/10.3390/app10082837. 
7. Feizi, R.; Jorfi, S.; Takdastan, A., Bioremediation of phenanthrene-polluted soil using Bacillus kochii AHVKH14 as a halo-tolerant strain isolated from compost. Environmental Health Engineering and Management Journal 2020, 7, 23-30, http://dx.doi.org/10.34172/EHEM.2020.04.

8. Patel, A. B.; Shaikh, S.; Jain, K. R.; Desai, C.; Madamwar, D., Polycyclic Aromatic Hydrocarbons: Sources, Toxicity and Remediation Approaches. Frontiers in Microbiology 2020, 11, 2675, https://doi.org/10.3389/fmicb.2020.562813.

9. Mancera-López, M.; Esparza-García, F.; Chávez-Gómez, B.; Rodríguez-Vázquez, R.; Saucedo-Castaneda, G.; Barrera-Cortés, J., Bioremediation of an aged hydrocarbon-contaminated soil by a combined system of biostimulation-bioaugmentation with filamentous fungi. International Biodeterioration \& Biodegradation 2008, 61, 151-160, https://doi.org/10.1016/j.ibiod.2007.05.012.

10. Girijan, S.; Kumar, M., Microbial Degradation of Pharmaceuticals and Personal Care Products from Wastewater. In Microbial Bioremediation \& Biodegradation, Springer: 2020; 173-201, https://doi.org/10.1007/978-981-15-1812-6_8.

11. Li, X.; Wang, X.; Zhang, Y.; Cheng, L.; Liu, J.; Li, F.; Gao, B.; Zhou, Q., Extended petroleum hydrocarbon bioremediation in saline soil using Pt-free multianodes microbial fuel cells. Rsc Advances 2014, 4, 5980359808, https://doi.org/10.1039/C4RA10673C.

12. Cui, J.-Q.; He, Q.-S.; Liu, M.-H.; Chen, H.; Sun, M.-B.; Wen, J.-P., Comparative study on different remediation strategies applied in petroleum-contaminated soils. International journal of environmental research and public health 2020, 17, 1606, https://doi.org/10.3390/ijerph17051606.

13. Yu, Y.; Zhang, Y.; Zhao, N.; Guo, J.; Xu, W.; Ma, M.; Li, X., Remediation of crude oil-polluted soil by the bacterial rhizosphere community of Suaeda Salsa revealed by $16 \mathrm{~S}$ rRNA genes. International journal of environmental research and public health 2020, 17, (5), 1471, https://doi.org/10.3390/ijerph17051471.

14. Kumar, V.; Thakur, I. S.; Shah, M. P., Bioremediation Approaches for Treatment of Pulp and Paper Industry Wastewater: Recent Advances and Challenges. Microbial Bioremediation \& Biodegradation 2020, 1-48, https://doi.org/10.1007/978-981-15-1812-6_4.

15. Yudono, B.; Said, M.; Napoleon, A.; Fanani, Z., Kinetics approach of biodegradation of petroleum contaminated soil by using indigenous isolated bacteria. Journal of Tropical Soils, 2013, 16, 33-38. https://doi.org/10.5400/jts.2011.16.1.33.

16. Kumar, R.; Kundu, S. Microbial Bioremediation and Biodegradation of Hydrocarbons, Heavy Metals, and Radioactive Wastes in Solids and Wastewaters. In Microbial Bioremediation \& Biodegradation, Springer: 2020; 95-112.

17. Deepa, A.; Mishra, B. K., Microbial biotransformation of hexavalent chromium [Cr (VI)] in tannery wastewater. In Microbial Bioremediation \& Biodegradation, Springer, 2020; 143-152, https://doi.org/10.1007/978-981-15-1812-6_4.

18. Landa-Acuña, D.; Acosta, R. A. S.; Cutipa, E. H.; de la Cruz, C. V.; Alaya, B. L., Bioremediation: A LowCost and Clean-Green Technology for Environmental Management. In Microbial Bioremediation \& Biodegradation, Springer, 2020; 153-171. https://doi.org/10.1007/978-981-15-1812-6_7.

19. Pineda, S. P.; Vásquez, J. C. H., Conventional and Nonconventional Biodegradation Technologies for AgroIndustrial Liquid Waste Management. In Microbial Bioremediation \& Biodegradation, Springer, 2020; pp 251-265, https://doi.org/10.1007/978-981-15-1812-6_10.

20. Azadi, D.; Shojaei, H., Biodegradation of polycyclic aromatic hydrocarbons, phenol and sodium sulfate by Nocardia species isolated and characterized from Iranian ecosystems. Scientific reports 2020, 10, 1-12, https://doi.org/10.1038/s41598-020-78821-1.

21. Deng, Z.; Jiang, Y.; Chen, K.; Gao, F.; Liu, X., Petroleum depletion property and microbial community shift after bioremediation using Bacillus halotolerans T-04 and Bacillus cereus 1-1. Frontiers in microbiology 2020, 11, 353, https://doi.org/10.3389/fmicb.2020.00353.

22. Sima, N. A. K.; Ebadi, A.; Reiahisamani, N.; Rasekh, B., Bio-based remediation of petroleum-contaminated saline soils: Challenges, the current state-of-the-art and future prospects. Journal of environmental management 2019, 250, 109476, https://doi.org/10.1016/j.jenvman.2019.109476.

23. Talley, J. W., Roadblocks to the implementation of biotreatment strategies. In Bioremediation of recalcitrant compounds, CRC Press: 2016,41-58, https://doi.org/10.1111/j.1749-6632.1997.tb48562.x.

24. Taccari, M.; Milanovic, V.; Comitini, F.; Casucci, C.; Ciani, M., Effects of biostimulation and bioaugmentation on diesel removal and bacterial community. International Biodeterioration \& Biodegradation 2012, 66, 39-46, https://doi.org/10.1016/j.ibiod.2011.09.012. 
25. Linos, A.; Steinbuchel, A., Microbial degradation of natural and synthetic rubbers by novel bacteria belonging to the genus Gordona. Kautschuk Gummi Kunststoffe 1998, 51, 496-499.

26. Jorfi, S.; Rezaee, A.; Mobeh-Ali, G.-A.; Jaafarzadeh, N. A., Application of biosurfactants produced by Pseudomonas aeruginosa SP4 for bioremediation of soils contaminated by pyrene. Soil and Sediment Contamination: An International Journal $\quad$ 2013, $22, \quad$ 890-911, https://doi.org/10.1080/15320383.2013.770439.

27. Kalantary, R. R.; Badkoubi, A.; Mohseni-Bandpi, A.; Esrafili, A.; Jorfi, S.; Dehghanifard, E.; Baneshi, M. M., Modification of PAHs biodegradation with humic compounds. Soil and sediment contamination: An international journal 2013, 22, 185-198, https://doi.org/10.1080/15320383.2013.722139.

28. Mendpara, J.; Parekh, V.; Vaghela, S.; Makasana, A.; Kunjadia, P. D.; Sanghvi, G.; Vaishnav, D.; Dave, G. S., Isolation and characterization of high salt tolerant bacteria from agricultural soil. Eur. J. Exp. Biol 2013, 3, 351-358, https://doi.org/10.1080/01490451.2014.917743.

29. Leite, M. C.; de Farias, A. R.; Freire, F. J.; Andreote, F. D.; Kuklinsky-Sobral, J.; Freire, M. B., Isolation, bioprospecting and diversity of salt-tolerant bacteria associated with sugarcane in soils of Pernambuco, Brazil. Revista Brasileira de Engenharia Agrícola e Ambiental 2014, 18, 73-79, https://doi.org/10.1590/18071929/agriambi.v18nsupps73-s79.

30. Casellas, M.; Grifoll, M.; Sabaté, J.; Solanas, A. M., Isolation and characterization of a 9-fluorenonedegrading bacterial strain and its role in synergistic degradation of fluorene by a consortium. Canadian journal of microbiology 1998, 44, 734-742, https://doi.org/10.1139/w98-066.

31. Babu, A. G.; Reja, S. I.; Akhtar, N.; Sultana, M.; Deore, P. S.; Ali, F. I., Bioremediation of Polycyclic Aromatic Hydrocarbons (PAHs): Current Practices and Outlook. In Microbial Metabolism of Xenobiotic Compounds, Springer, 2019, 189-216, https://doi.org/10.1007/978-981-13-7462-3_9.

32. Qin, X.; Tang, J.; Li, D.; Zhang, Q., Effect of salinity on the bioremediation of petroleum hydrocarbons in a saline-alkaline soil. Letters in applied microbiology 2012, 55, 210-217, https://doi.org/10.1111/j.1472765X.2012.03280.x.

33. Børresen, M.; Rike, A., Effects of nutrient content, moisture content and salinity on mineralization of hexadecane in an Arctic soil. Cold regions science and technology 2007, 48, 129-138, https://doi.org/10.1016/j.coldregions.2006.10.006.

34. Pino-Herrera, D. O.; Pechaud, Y.; Huguenot, D.; Esposito, G.; Van Hullebusch, E. D.; Oturan, M. A., Removal mechanisms in aerobic slurry bioreactors for remediation of soils and sediments polluted with hydrophobic organic compounds: An overview. Journal of hazardous materials 2017, 339, 427-449, https://doi.org/10.1016/j.jhazmat.2017.06.013.

35. Wong, A.; Goldsmith, C., The impact of a chemostat discharge containing oil degrading bacteria on the biological kinetics of a refinery activated sludge process. Water Sci Technol 1988, 20, 131-136, https://doi.org/10.2166/wst.1988.0276.

36. Lee, P.-H., Use of solvents for PAHs extraction and enhancement of the PAHs bioremediation in coal-tarcontaminated soils. 2000, https://doi.org/10.31274/rtd-180813-15266.

37. Rehmann, L.; Prpich, G. P.; Daugulis, A. J., Remediation of PAH contaminated soils: Application of a solidliquid two-phase partitioning bioreactor. Chemosphere 2008, 73, 798-804, https://doi.org/10.1016/j.chemosphere.2008.06.006.

38. Saez, J. M.; Álvarez, A.; Benimeli, C. S.; Amoroso, M. J., Enhanced lindane removal from soil slurry by immobilized Streptomyces consortium. International Biodeterioration \& Biodegradation 2014, 93, 63-69, https://doi.org/10.1016/j.ibiod.2014.05.013.

39. Liu, X.-X.; Hu, X.; Cao, Y.; Pang, W.-j.; Huang, J.-y.; Guo, P.; Huang, L., Biodegradation of phenanthrene and heavy metal removal by acid-tolerant Burkholderia fungorum FM-2. Frontiers in microbiology 2019, 10, 408, https://dx.doi.org/10.3389\%2Ffmicb.2019.00408.

40. Košnáŕ, Z.; Wiesnerová, L.; Částková, T.; Kroulíková, S.; Bouček, J.; Mercl, F.; Tlustoš, P., Bioremediation of polycyclic aromatic hydrocarbons (PAHs) present in biomass fly ash by co-composting and covermicomposting. Journal of hazardous materials 2019, 369, 79-86, https://doi.org/10.1016/j.jhazmat.2019.02.037. 